\title{
マイクロボールエンドミルの回転振れが摩耗特性および切削抵抗に及ぼす影響*
}

\author{
浜口 和也 ${ }^{* 1}$ ，平山 明宏 ${ }^{* 1}$ ，静 弘生 ${ }^{* 2}$ ，奥田 孝一 ${ }^{* 2}$
}

\section{Effect of Run-Out on Tool Wear Characteristics and Cutting Forces in Micro Ball End Mill}

\author{
Kazuya HAMAGUCHI ${ }^{* 1}$, Akihiro HIRAYAMA, Hiroo SHIZUKA and Koichi OKUDA \\ ${ }^{* 1}$ Hyogo Prefectural Institute of Technology \\ 3-1-12 Yukihira-cho, Suma-ku, Kobe, Hyogo, 654-0037 Japan
}

This paper describes the effect of the run-out on the tool wear and the cutting force in micro ball end milling. The cutting tests were carried out with the micro ball end mill that has a geometry consisting of two flutes and the radius of $200 \mu \mathrm{m}$. The run-out was generated by inserting the micro ball end mill and the shim in the collet. The spindle speed was fixed at a constant value of $15000 \mathrm{~min}^{-1}$ minimized the repeatable run-out and the non-repeatable run-out. When the thickness of shim was varied in $0.01,0.03$, and $0.05 \mathrm{~mm}$, the run-out was 6,20 , and $38 \mu \mathrm{m}$ respectively. As a result, the difference of maximum flank wear in two flutes increased with an increase in the run-out. The difference of the maximum flank wear in two flutes increased near the center of the micro ball end mill. The average cutting force was not dependent on the run-out, however, the difference of the cutting force acting on two flutes increased with an increase in the run-out.

Key Words : Micro Ball End Mill, Run-Out, Tool Wear, Cutting Force, Metal Mold and Die

\section{1. 緒言}

近年, 光学機器，医療機器，電子機器分野などにおける製品の小型化，高機能化により，微細な形状を有する 部品が増えている.このような微細形状の加工には，直径 $1 \mathrm{~mm}$ 以下のマイクロエンドミルを用いた切削加工が 低コストや短納期を実現できる加工技術として有望視されている. しかしながら, マイクロエンドミル加工では, 従来のエンドミル加工で無視できていた高速回転中の振れが問題となっている.

これまで，マイクロエンドミルに発生する振れが加工面性状や加工精度に及ぼす影響については報告されてい る(1)(2).また，振れが発生したときの切削抵抗に関する報告もあるが(3)，これらのほとんどはマイクロスクウェア エンドミルに関寸る研究である。ボールエンドミル加工に関しては, 直径数 $\mathrm{mm}$ 以上の従来ボールエンドミルに 発生する振れと加工面性状との関係についての報告はあるが(4)，マイクロボールエンドミルに関しては研究され ていない.

微細な 3 次元形状加工では高い精度が要求されるため，マイクロボールエンドミルの摩耗抑制が必要不可欠と なる．このため，著者らはマイクロボールエンドミルの摩耗特性の解明についてこれまで取り組んできた ${ }^{(5)}$. 今 後もエンドミルの小径化は進み, マイクロボールエンドミル直径に対する振れ量の割合は増加すると考えられる が，その影響は明らかにされていない．このため，マイクロボールエンドミル加工では，高速回転中の振れの影 響も考慮して摩耗特性を解明しなければならない.

そこで本研究では，マイクロボールエンドミルに強制的に振れを与えて加工実験を行い，振れ量が摩耗形態や

\footnotetext{
* 原稿受付 2012 年 1 月 4 日

*1 正員，兵庫県立工業技術センター（†654-0037 兵庫県神戸市須磨区行平町 3-1-12）

*2 正員, 兵庫県立大学大学院工学研究科 (T671-2201 兵庫県姫路市書写 2167)

E-mail: kazuya@hyogo-kg.jp
} 
切削抵抗に及ぼす影響について検討した。

\section{2. 実験方法}

\section{$2 \cdot 1$ 振れの発生方法および測定方法}

図 1 は，マイクロボールエンドミルに振れを発生させる方法を示したものである. 振れはマイクロボールエン ドミルとステンレス製のシムをコレット（大昭和精機 NBC13-4.5AA）で把持することによって発生させた.シ ムの幅は $6 \mathrm{~mm}$ でシャンク部外周を約 $180^{\circ}$ 覆い, 長さはコレットの把持長さと同じ $20 \mathrm{~mm}$ である. 振れ量は, 厚さ $0.01 ， 0.03 ， 0.05 \mathrm{~mm}$ の 3 種類のシムを用いることによって変化させた. マイクロボールエンドミルの切れ 刃とシムとの位置関係は図 1 に示したとおりである. シムを把持することによって主軸の回転中心から離れる切 れ刃は A，近づく切れ刃はB とした.

高速回転中における振れ量の測定には，撮像式の非接触振れ量測定装置（侏ジェイネット製 ジェイコア）を使 用した. 測定分解能は $0.1 \mu \mathrm{m}$ である. マイクロボールエンドミルの刃先は複雑な形状を有するため, 振れ量の測 定は刃先から $0.5 \mathrm{~mm}$ の位置にある切れ刃が存在しない首下部で行った.

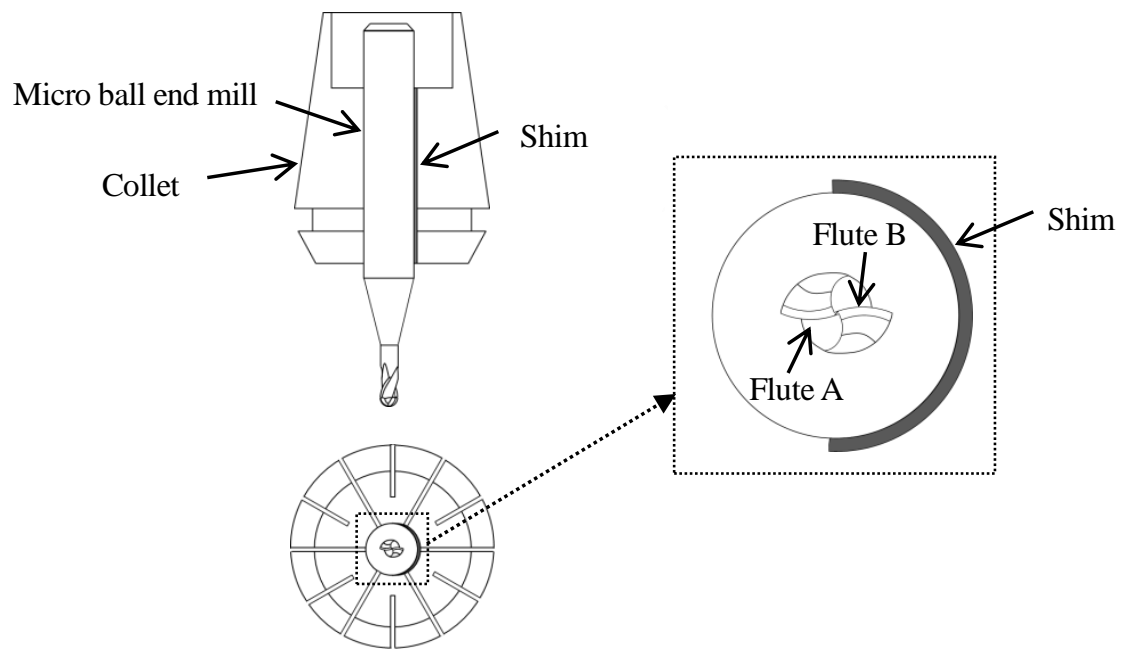

Fig.1 Method for generating run-out

\section{$2 \cdot 2$ 主軸回転数の選定}

高速回転中における共振の影響を避けるため, マイクロボールエンドミルとシムを把持した状態で，振れ量が 最も小さくなる回転数について調べた。 このときの振れは，回転に同期する振れと同期しない振れが合成された ものであるため( ${ }^{()}$, 主軸回転数はそれぞれの振れについて検討した.

図 2 は，主軸回転数と回転に同期する振れ量との関係を示したものである. シムの厚さに関係なく，主軸回転 数 $25000 \mathrm{~min}^{-1}$ 以上で振れ量が急増しており，この回転数付近に共振回転領域が存在することがわかる.このため, 回転に同期寸る振れの特性から, 実験に適している主軸回転数は $20000 \mathrm{~min}^{-1}$ 以下であることがわかった. 図 3 は, 主軸回転数 $20000 \mathrm{~min}^{-1}$ 以下における主軸回転数と回転に同期しない振れ量との関係を示したものである.いずれ のシムを用いた場合でも, 主軸回転数 $15000 \mathrm{~min}^{-1}$ における振れ量が最も小さいことがわかる. したがって, 本実 験における主軸回転数は $15000 \mathrm{~min}^{-1}$ とした.

シム厚さが $0.01 ， 0.03 ， 0.05 \mathrm{~mm}$ のとき, 主軸回転数 $15000 \mathrm{~min}^{-1}$ における振れ量はそれぞれ $6,20,38 \mu \mathrm{m}$ であ った. この振れ量は強制的に発生させたものであるため，一般の主軸では発生しにくい，そこで本研究における 評価には，W.Y. Bao らと同椂にエンドミル直径に対する振れ量の割合（run-out per diameter，以下 R/D）を用いた

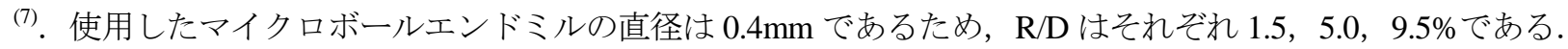




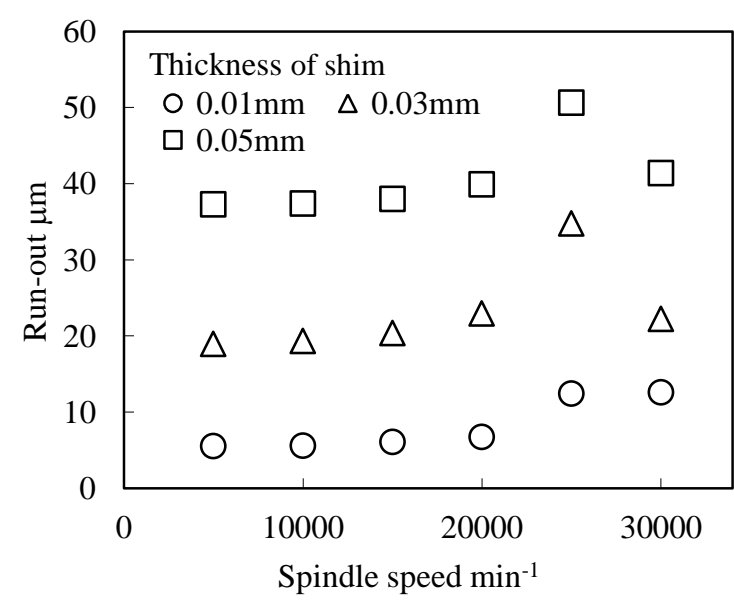

Fig. 2 Relationship between repeatable run-out and spindle speed

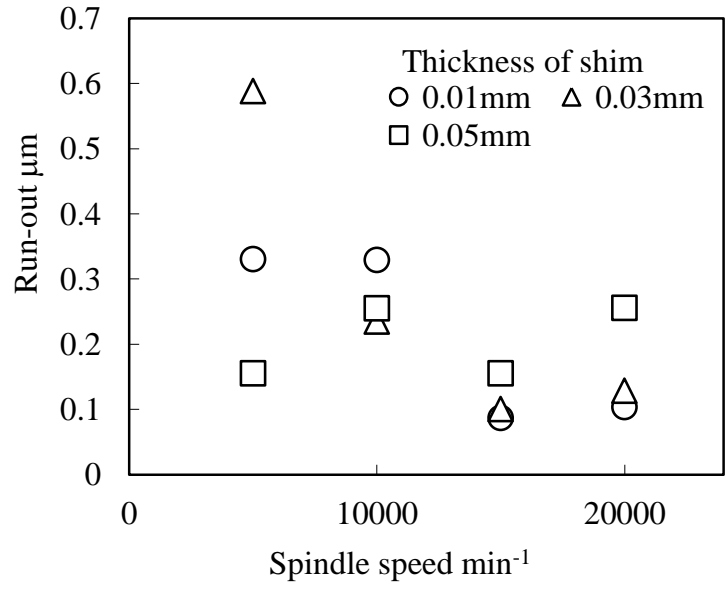

Fig. 3 Relationship between non-repeatable run-out and spindle speed

\section{$2 \cdot 3$ 切削加工条件}

切削加工実験には，高速回転主軸を搭載した NC フライス盤（東芝機械侏製 ASV400）を用いた．被削材は， 硬さ52HRC まで焼入処理してあるステンレス鋼（ウッデホルム怢製 STAVAX）である. 加工形状は，4×25 mm， 加工深さ $20 \mu \mathrm{m}$ の平面加工である. 使用したマイクロボールエンドミルは, 2 枚刃, 刃先半径 $0.2 \mathrm{~mm}$, 刃長 $0.4 \mathrm{~mm}$, 首下長 $2 \mathrm{~mm}$ の超硬合金製エンドミル（三菱マテリアル侏製 MS2XLB）であり，TiAlN コーティングを施してい る.コレットチャックからのマイクロボールエンドミルの突出し量は $20 \mathrm{~mm}$ である. 図 4 はマイクロボールエン ドミルの移動経路を示したものである. 切削方向をダウンカットとするため, ピックフィードはX方向，送りは $\mathrm{Y}$ 方向に与えた. 主な切削加工条件は表 1 に示寸.

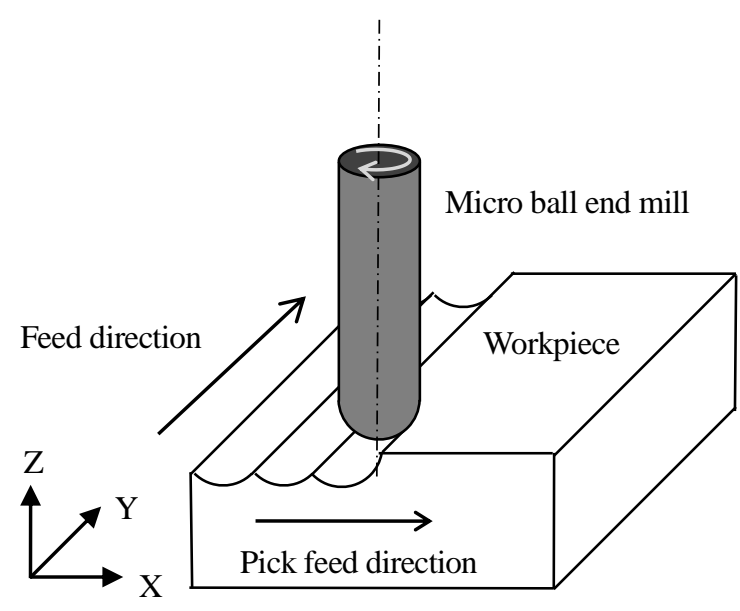

Fig. 4 Definition of cutting and feed direction
Table 1 Cutting conditions

\begin{tabular}{|l|c|}
\hline Tool material & Cemented carbide \\
\hline Radius of ball end mill & $0.2 \mathrm{~mm}$ \\
\hline Neck length & $2 \mathrm{~mm}$ \\
\hline Rake angle & $25^{\circ}$ \\
\hline Number of teeth & Stainless steel (52HRC) \\
\hline Workpiece material & $15000 \mathrm{~min}^{-1}$ \\
\hline Rotation speed of spindle & $6,20,38 \mu \mathrm{m}$ \\
\hline Run-out & $1.5,5.0,9.5 \%$ \\
\hline Run-out per diameter & $10 \mu \mathrm{m} / \mathrm{tooth}$ \\
\hline Feed rate & $300 \mathrm{~mm} / \mathrm{min}^{\circ}$ \\
\hline Feed & $20 \mu \mathrm{m}$ \\
\hline Pick feed & $20 \mu \mathrm{m}$ \\
\hline Depth of cut & Dry \\
\hline Cooling condition & \\
\hline
\end{tabular}

\section{3. 実験結果および考察}

\section{$3 \cdot 1$ 振れが摩耗形態に及ぼす影響}

振れがマイクロボールエンドミルの摩耗形態に及ぼす影響を調べるため, デジタルマイクロスコープ（侏ハイ ロックス製 KH-7700）を用いて，切削加工後の刃先観察および逃げ面摩耗幅の測定を行った，刃先観察はマイク 
ロボールエンドミルの最先端部に対して行った．図 5 は，逃げ面摩耗幅を測定するときの模式図である． 2 枚刃 のマイクロボールエンドミルを使用したため, それぞれの切れ刃について逃げ面摩耗幅を測定した. 矢印 Cで示 す円弧部は, 寸くい角などの刃先形状が測定範囲の切れ刃とは異なるため, 測定対象から外している.このため, 逃げ面摩耗幅はエンドミルの中心から $30 \mu \mathrm{m}$ 離れた位置を基点として $10 \mu \mathrm{m}$ 毎に測定した.

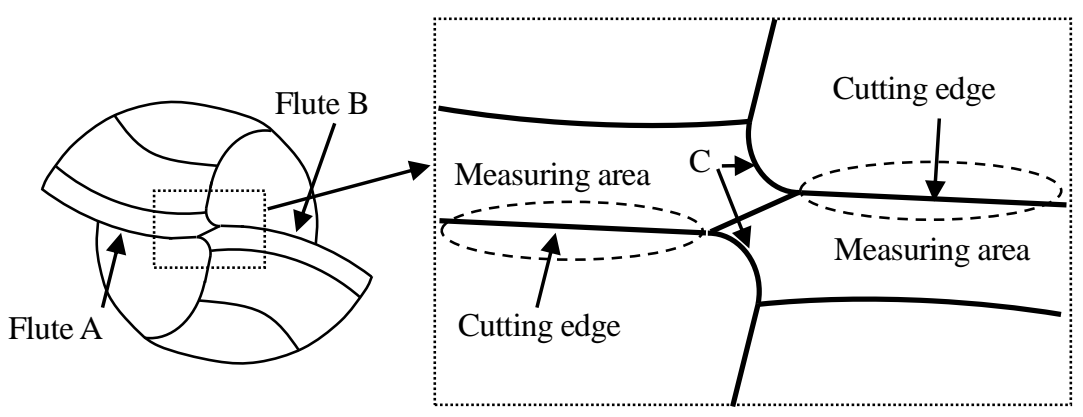

Fig. 5 Measuring area of flank wear in micro ball end mill

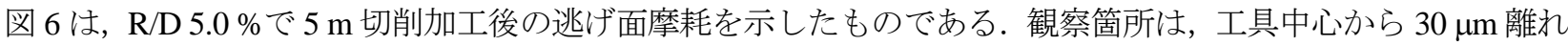
た位置を基点として外周部に向かう切れ刃部である. 図 6(a)と(b)は同じマイクロボールエンドミルにおける切れ 刃であり, 中心からの距離も等しいが，摩耗形態は異なることがわかる. 従来の 2 枚刃ボールエンドミルにおけ る摩耗は, 工具中心部付近に発生する摩耗と, 円弧部に生じる逃げ面摩耗に分類されており, 両切れ刃の摩耗形 態は対称である.しかし，振れが伴うマイクロボールエンドミルでは，切れ刃 A が工具中心部に生じる摩耗，切 れ刃 B が逃げ面摩耗と同様の摩耗形態となり，これらは非対称となっている．このため，振れがマイクロボール エンドミルの逃げ面摩耗形態に影響を及ぼすことがわかる.

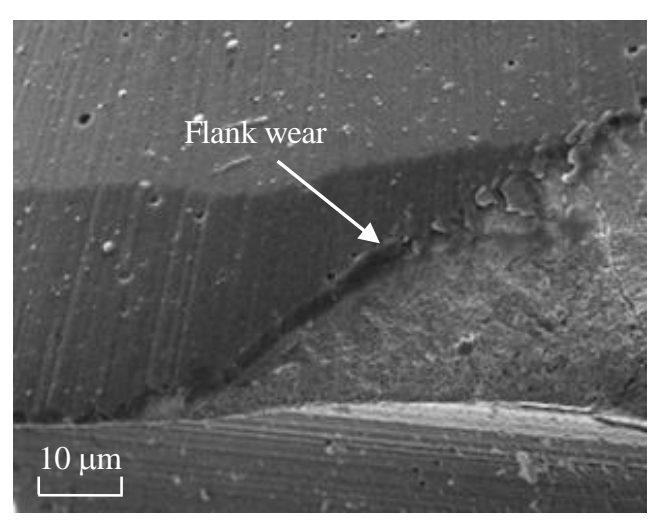

(a) Flute A

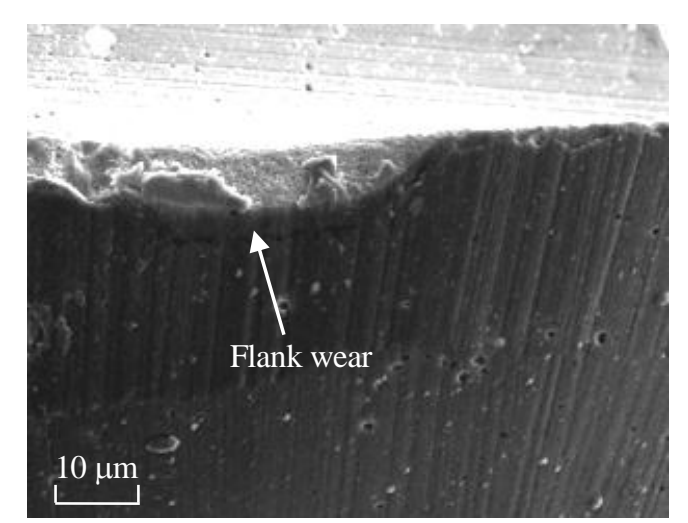

(b) Flute B

Fig. 6 SEM images of tool wear

図 7 は, $5 \mathrm{~m}$ 切削加工後における工具中心からの切れ刃位置と逃げ面摩耗幅との関係を示したものである. 横 軸の 0 点が工具中心であり, 切れ刃 $\mathrm{A}$ の逃げ面摩耗幅は左側, 切れ刃 $\mathrm{B}$ は右側に示した. いずれの $\mathrm{R} / \mathrm{D}$ におい ても, 切れ刃 A の逃げ面摩耗幅は切れ刃 B に比べて大きいことがわかる. R/D の増加に伴い, 切れ刃 A の逃げ 面摩耗幅は増加しているが，反対に切れ刃 B では減少している．このため， R/D $1.5 \%$ のき $6.3 \mu \mathrm{m}$ であった最 大逃げ面摩耗幅の差は, R/D が $5.0 \%$ ，9.5\%と増加するにつれて，それぞれ $15.7 \mu \mathrm{m}, 38.4 \mu \mathrm{m}$ と増大している. これより, マイクロボールエンドミルに発生する振れ量は, 両切れ刃における最大逃げ面摩耗幅の差を増大させ ることがわかった。 


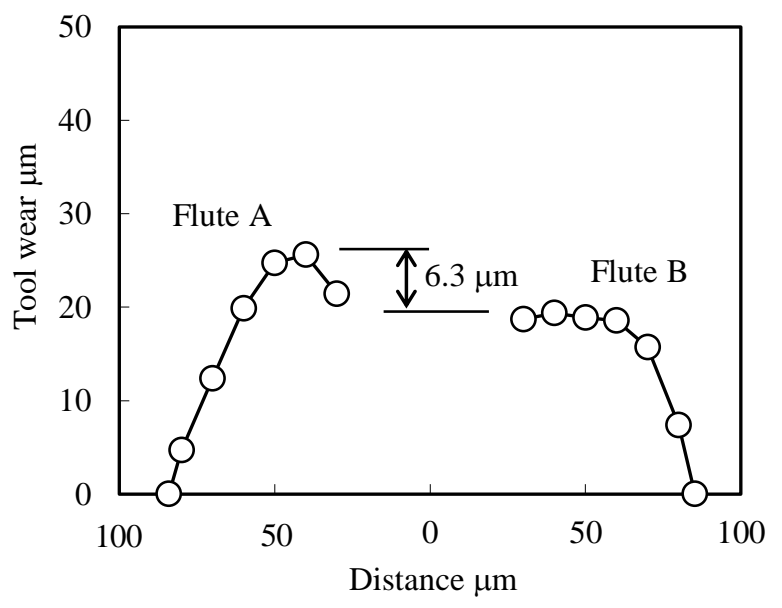

(a) R/D $1.5 \%$

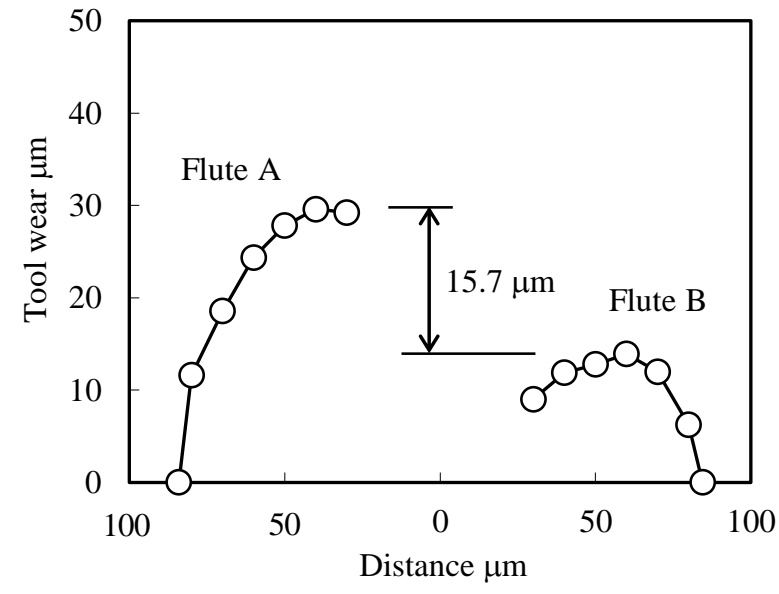

(b) R/D $5.0 \%$

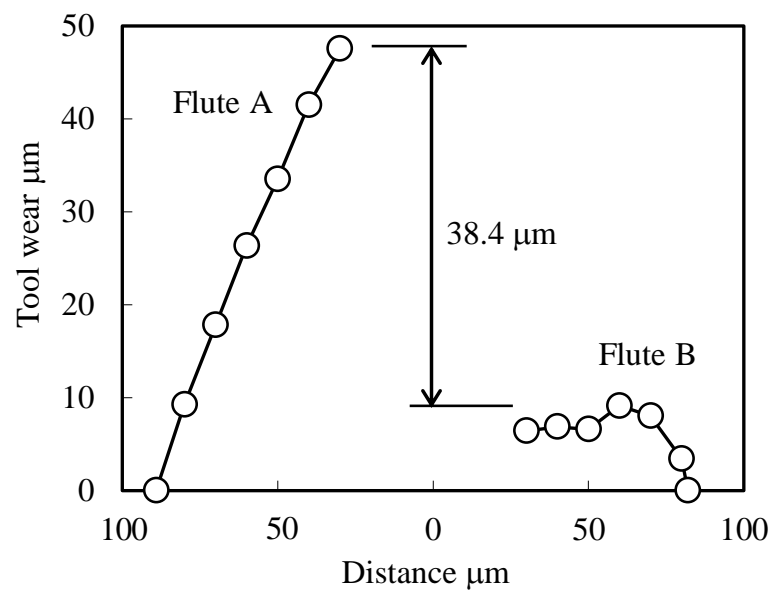

(c) R/D $9.5 \%$

Fig. 7 Relationship between flank wear and distance from tool center

ボールエンドミル加工において逃げ面摩耗に影響を及ぼす主な因子は，切れ刃が被削材を擦過する実切削距離 および切削速度である ${ }^{(8)}$. 本実験では主軸回転数を $15000 \mathrm{~min}^{-1}$ で固定しているため，切削速度は一定である. このため, 実切削距離が逃げ面摩耗幅に影響を及ぼす主な因子と考えられることから, 振れ量と実切削距離との 関係について検討した. 図 8 はR/D $1.5 \%$ における工具中心から約 $80 \mu \mathrm{m}$ 離れた箇所の切れ刃軌跡を示したもの である. 切れ刃 $\mathrm{A}$ は曲線 $\mathrm{AC}$, 切れ刃 B は曲線 BD を通って被削材を削る. 振れ量がゼロの場合, 曲線 $\mathrm{AC}$ とD は等しくなるが，振れの発生よって切れ刃 $\mathrm{A}$ の回転半径が大きくなり，曲線 $\mathrm{AC}$ が $\mathrm{BD}$ に比べて長くなる. さら に R/D が増加すると, 曲線 $\mathrm{AC}$ は長くなり, 反対に曲線 $\mathrm{BD}$ は短くなっていく. 実切削距離は図 8 に示す曲線 $\mathrm{AC}$ と BD が累積されたものであるため，この差が最大逃げ面摩耗幅の差につながったと考えられる.よって，振れ の発生が切れ刃の回転半径を増減させることにより，最大逃げ面摩耗幅に差が生じることがわかった。

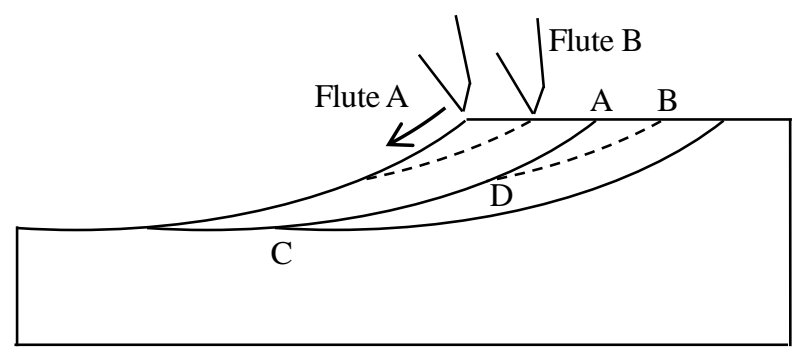

Fig. 8 Trajectory of two flutes 


\section{$3 \cdot 2$ 両切れ刃における工具中心からの距離と摩耗幅との関係}

両切れ刃における逃げ面摩耗形態の差異を明らかにするため，工具中心からの位置と逃げ面摩耗幅の差につい て調べた. 図 9 は, 工具中心からの切れ刃の位置と両切れ刃における逃げ面摩耗幅の差を示したものである. R/D 1.5\%における逃げ面摩耗幅の差は工具中心からの位置に関係なくほぼ一定の值となっている. これに対して, R/D 5.0\%，R/D 9.5\%における逃げ面摩耗幅の差は，工具中心から $80 \mu \mathrm{m}$ 離れた位置では R/D 1.5\%とほぼ同じ值である が，工具中心に向かうほど増加している．さらに，その増加傾向は R/D 9.5\%が R/D 5.0\%に比べ大きくなっている ことがわかる。

図 7 における切れ刃 $\mathrm{A}$ に着目すると, 工具中心から離れた箇所では, いずれの R/D についても逃げ面摩耗幅は 同様の増加傾向を示している．しかし，工具中心に近い箇所では， R/D が大きいものほど逃げ面摩耗幅が増加し ていることがわかる。これとは反対に，切れ刃 B では R/D が小さいものほど工具中心に近い箇所で逃げ面摩耗幅 は増加している. 振れの発生によって実切削距離が最も短くなるのは R/D 9.5\%における切れ刃 B であり，切れ刃 $\mathrm{B}$ の R/D 5.0\%，1.5\%，切れ刃 A の R/D 1.5\%，5.0\%，9.5\%の順で実切削距離は長くなる。この実切削距離と図 7 の摩耗形態の関係から，切削加工初期には工具中心から離れた箇所で摩耗が進展し，切削距離が延びるにつれて 中心付近の摩耗が徐々に進展していくことがわかる．図 9 に示寸ように工具中心付近における逃げ面摩耗幅の差 が外周部に比べて大きくなったのは，摩耗進展の違いによるものと考えられる．以上の結果から，逃げ面摩耗幅 の差は工具中心に近づくにつれて増加し，R/D の増加に伴いその差は増大寸ることがわかった.

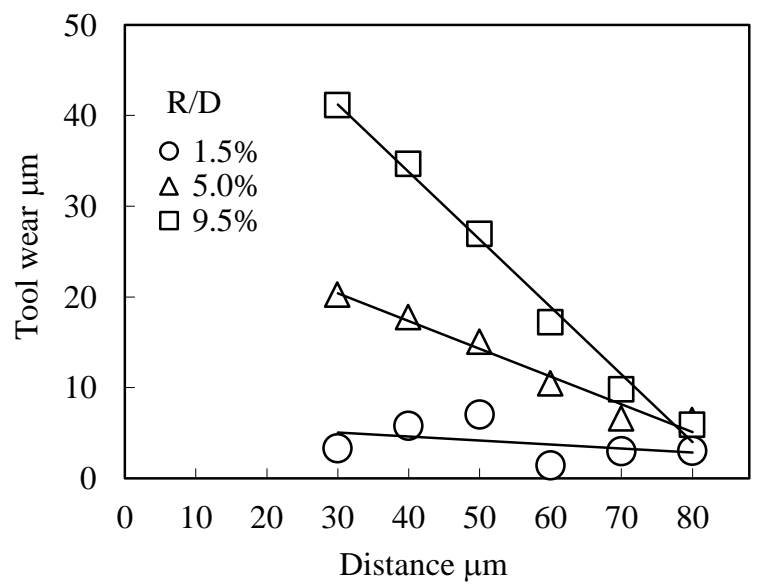

Fig. 9 Relationship between difference of flank wear in two flutes and distance from tool center

\section{$3 \cdot 3$ 振れが切削抵抗に及ぼす影響}

振れが切削抵抗に及ぼす影響を調べるため，3成分小型切削動力計（㑣日本キスラー製 9256C）を用いて，切 削加工中の切削抵抗を測定した．測定は切削距離 $1 \mathrm{~m}$ 毎に実施し，測定範囲は 1 パス $25 \mathrm{~mm}$ である. 図 10 は, R/D 1.5\%における切削抵抗の平均值を示したものである. 図 4 で示したピックフィード方向，送り方向，深さ方 向に対する切削抵抗は，それぞれ Fx，Fy，Fz とした．いずれの方向についても，切削距離が延びるにつれて切 削抵抗の平均值は増加していることがわかる．本実験では，切削距離とともに増加寸る因子は切れ刃に発生する 摩耗のみであるため，切削抵抗の平均值の増加は刃先の摩耗によるものと考えられる.

切削距離 $1 \mathrm{~m}$ では，Fx，Fy はほぼ同じ值であるが，Fz はこれらの2 倍以上である．従来のボールエンドミル 加工では切削速度が増加するほど切削抵抗が減少するため ${ }^{(10)}$ ，工具中心部付近における切削速度の低下が深さ方 向の切削抵抗を増大させたものと考えられる. さらに切削距離 $5 \mathrm{~m}$ においては, Fz と Fx, Fy との差はさらに広 がり，深さ方向に対する切削抵抗が，ピックフィード方向，送り方向に比べて著しく増加することがわかる．こ れは，図７で示したように，工具中心部付近における摩耗が外周部に比べて進展するためと考えられる.

図 10 における切削抵抗の平均值と切削距離との関係は，マイクロ CBN エンドミルを用いて SKD11 を切削加 工したときの切削抵抗の平均值と同様の傾向を示している(11). また，R/D 5.0\%，R/D 9.5\%における切削抵抗の平 均值は，R/D 1.5\%と同様の増加傾向となっていた．振れが発生することによって逃げ面摩耗形態や切取り量は変 
化するが， 2 枚刃にかかる切削抵抗が平均されたためと考えられる. したがって，切削抵抗の平均值は振れ量に 関係なくほぼ同様の傾向を示すことがわかった。

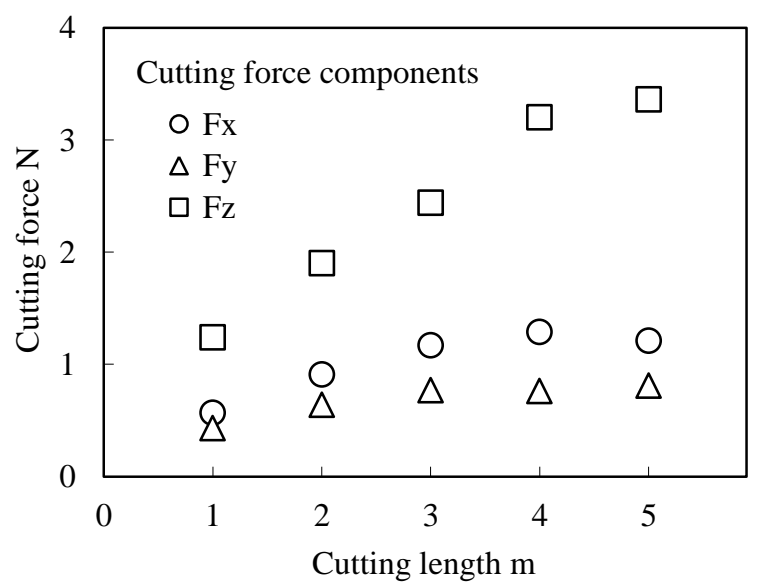

Fig. 10 Relationship between cutting force and cutting length at R/D 1.5\%

両切れ刃における摩耗形態が異なることから，それぞれの切れ刃にかかる切削抵抗についても調べた．マイク ロボールエンドミルが移動して被削材に接触する直前では負荷がかかっていないため，このときの切削抵抗をゼ ロとして測定を実施した. 図 11 は切削距離 $1 \mathrm{~m}$ 付近での送り方向に対する切削抵抗波形を示したものである. 1 回転にかかる周期は $4 \mathrm{~ms}$ である. 切れ刃 $\mathrm{A}$ にかかる切削抵抗は波形 $\mathrm{A}$, 切れ刃 $\mathrm{B}$ にかかるものは波形 $\mathrm{B}$ とした. 図 11(a)はR/D 1.5\%のときの切削抵抗波形を示しており，1回転中に高さの異なる 2 つの波形 $\mathrm{A}$ と B が存在して いることがわかる. これは両切れ刃が切削に関与していることを示している. 切れ刃 $\mathrm{A}$ の波形が高く, 切れ刃 $\mathrm{B}$ が低いのは, 振れの発生により回転半径が変化して, 切取り量に差ができたためと考えられる. これはマイクロ スクウェアエンドミルを用いたときの切削抵抗と一致しており ${ }^{(12)}$ ，マイクロボールエンドミルについても同様の 傾向が見られることがわかった。一方，R/D 5.0\%の切削抵抗波形を示寸図 11(b)では，1回転中に 1 つの波形しか 存在していないため, 切削に関与寸るのは切れ刃 A のみと考えられる. マイクロボールエンドミル加工において も，マイクロスクウェアエンドミルと同様に切削抵抗波形から振れの影響を確認できる.

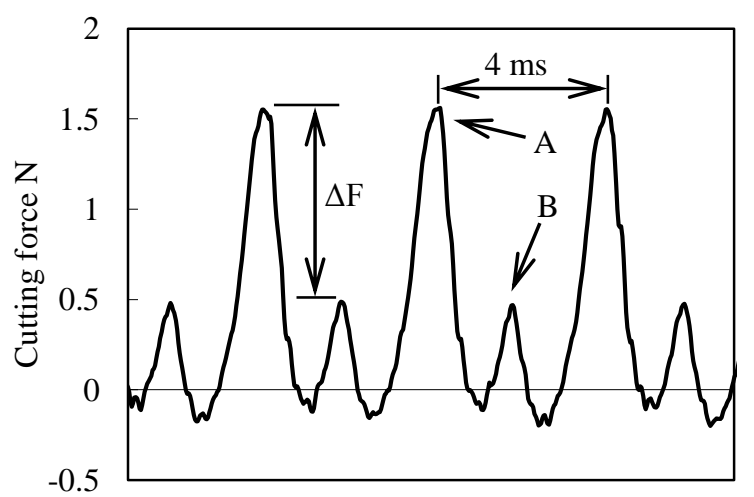

(a) R/D $1.5 \%$

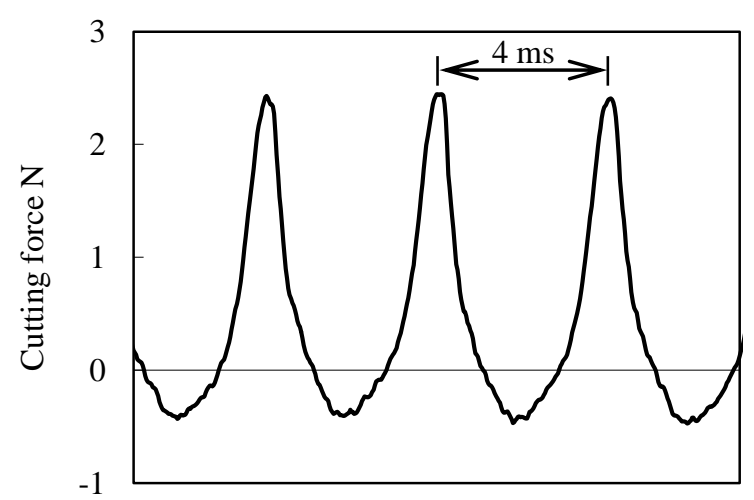

(b) R/D $5.0 \%$

Fig. 11 Cutting force signals in feed direction

両切れ刃にかかる切削抵抗に影響を及ぼす因子として，振れ以外にも摩耗が挙げられる．ここでは，摩耗が進 展したときの切削抵抗の変化を明らかにするため, 切れ刃 A と切れ刃 B における切削抵抗の差について調べた. 切削抵抗の差は, 図 11 における波形高さの差 $\Delta \mathrm{F}$ につて 5 回転分を平均して求めた. 図 12 は, 切削距離と切 
削抵抗の差との関係を示したものである. 切削抵抗がかかる方向に関係なく, R/D が大きなものほど，切削抵抗 の差が大きいことがわかる.

図 12(a)，(b)では，切削抵抗の差は R/D に関係なくほぼ同様の傾向を示している．R/D 1.5\%においては切削距 離の増加に伴い，切削抵抗の差は徐々に減少している。これは，切れ刃 A が摩耗することによって切取り量が減 少し, 反対に切れ刃 B の切取り量が増加したためと考えられる. 一方, R/D 5.0\%の切削抵抗の差は, 切削距離 $2 \mathrm{~m}$ まで増加しているが, 切削距離 $3 \mathrm{~m}$ 以降は減少している. 図 11(b)で示したように, 切削距離 $2 \mathrm{~m}$ までは切れ刃 $\mathrm{A}$ の夕が切削に関与するため, 切れ刃 $\mathrm{A}$ の摩耗の進展が切削抵抗の増加につながったと考えられる. 切削距離が延

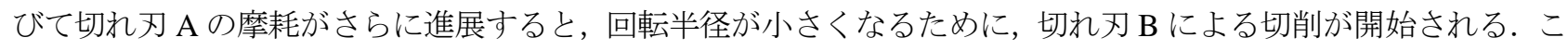
れにより, 両切れ刃の切取り量の差が小さくなり, 切削距離 $3 \mathrm{~m}$ 以降で切削抵抗の差が減少したと考えられる. R/D 9.5\%についても切削距離 $3 \mathrm{~m}$ 以降は増加傾向が認められないことから， R/D 5.0\%と同様の現象が生じている と推定できる.

図 12(c)において，R/D 1.5\%は図 12(a)，(b)と同様の傾向を示している．しかし，R/D 5.0\%，R/D 9.5\%は異なる 傾向を示しており, 深さ方向に対寸る切削抵抗の差はピックフィード方向, 送り方向とは異なることがわかる.

Fx，Fyには切れ刃の外周部が，Fzには工具中心部が影響を及ぼす。このため，R/D 5.0\%， R/D 9.5\%で切削抵抗 の差が異なる傾向を示したのは, 図 9 において工具中心部の逃げ面摩耗幅の差が増加したことが原因と考えられ る. さらに, R/D の増加に伴う切削抵抗の差の増加が図 9 の傾向と一致していることから, 逃げ面摩耗形態が切 れ刃にかかる切削抵抗の差に影響を及ぼすことがわかった。

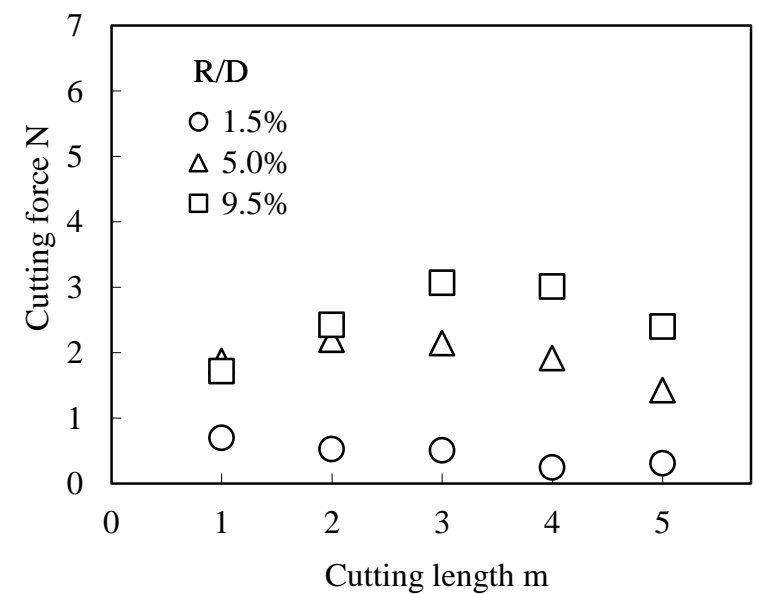

(a) Fx

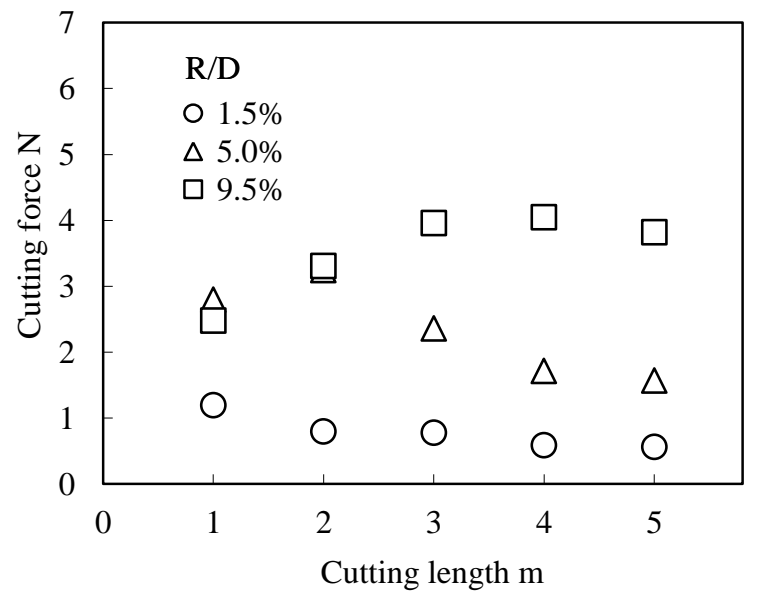

(b) Fy

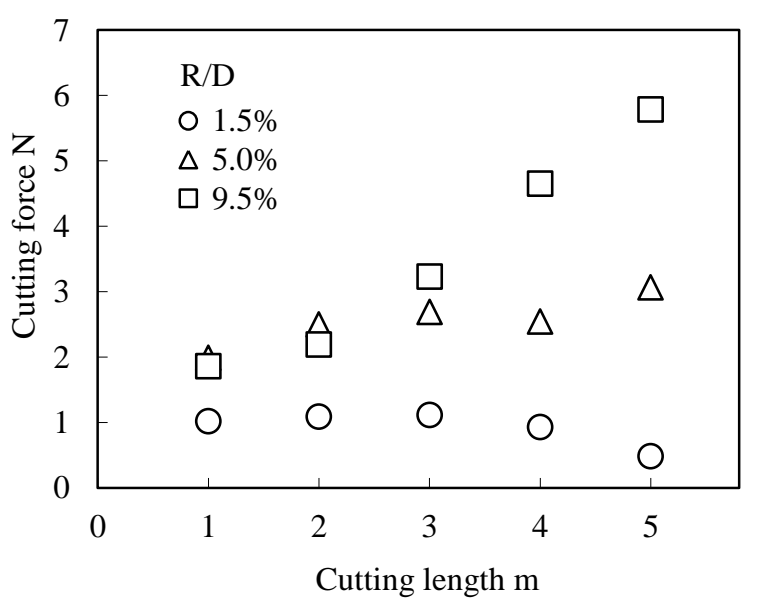

(c) $\mathrm{Fz}$

Fig. 12 Relationship between difference of cutting force and cutting length 


\section{4. 結}

マイクロボールエンドミル加工における振れの影響を明らかにするため, 振れ量を変化させた切削加工実験を 行った．振れ量と工具直径の割合から摩耗形態および切削抵抗について評価した結果，以下の結論が得られた.

（1）振れが発生することによって回転半径が大きくなる切れ刃 A は，従来ボールエンドミルの工具中心部に 発生する摩耗と同様の摩耗形態を示した。これに対して, 回転半径が小さくなる切れ刃 B では, 従来ボ ールエンドミルの円弧部に発生する逃げ面摩耗と同様の摩耗形態となり, マイクロボールエンドミル 2 枚刃の摩耗形態は非対称となる.

（2）振れの発生により切れ刃 $\mathrm{A}$ の最大逃げ面摩耗幅は増加するが，切れ刃 B では減少する. 振れ量の増加に 伴い, 両切れ刃における逃げ面摩耗幅の差は増加し, その差は工具中心に近づくほど大きくなる.

（3）切削抵抗の平均值は振れ量に影響されることなく，切削距離とともに増加する.

(4) R/D1.5\%において, 切削距離が延びるにつれて両切れ刃にかかる切削抵抗の差は減少する.一方, R/D 5.0\%, R/D 9.5\%では，ある切削距離まで切れ刃 A の摩耗増加により切削抵抗の差は増加するが，切れ刃 A の摩 耗が進展し，切れ刃 B の切取り量が増加することでその差は徐々に減少する.

以上の結果から，マイクロボールエンドミルの摩耗を抑制し，片側の切れ刃にかかる切削抵抗を増大させない ためには，R/D を1.5\%以下に抑えるべきであることを明らかにした.

\section{文献}

（1）成瀬哲也，上原嘉宏，片平和俊，水谷正義，大森整，小泉仁，“マイクロ切削に及ぼす機上工具作製の効果と表面 改質によるマイクロツールの強勒化”，砥粒加工学会誌，Vol. 53, No. 2 (2009), pp. 99-104.

（2）高橋渉，野村光由，桝田正美，柴田隆行，村上良彦，堀内宰，“微小径エンドミル加工における工具回転振れの加 工精度への影響”, 精密工学会秋季大会学術講演会論文集, (2010), pp. 39-40.

(3) G. Bissacco, H.N. Hansen, J. Slunsky, "Modeling the cutting edge radius size effect for force prediction in micro milling", CIRP Annals - Manufacturing Technology, Vol. 57, Issue 1 (2008), pp. 113-116

（4）柴原豪紀，熊谷幹人，幸田盛堂，奥田孝一，“工具回転精度が金型加工面テクスチヤに及ぼす影響”，砥粒加工学会 誌，Vol. 53, No. 4 (2009), pp. 230-235.

(5) K. Hamaguchi, H. Shizuka, K. Okuda, "Study on tool wear and cutting force in micro ball-end milling with high-speed spindle", Proceedings of International Conference of European Society for Precision Engineering and Nanotechnology, Vol.2, (2011), pp. 224-227.

（6）根深鉄平, 田中秀岳, 柳和久, “小径エンドミルの回転振れ軌跡と切れ刃プロファイルに基づく加工面性状の推定”, 精密工学会誌, Vol. 75, No. 5 (2009), pp. 645-649.

(7) W.Y. Bao, I.N. Tansel, "Modeling micro-end-milling operations. Part II: tool run-out", International Journal of Machine Tools and Manufacture, Vol. 40, No. 15 (2000), pp. 2175-2192.

(8) 高橋一郎, 安斎正博, 中川威雄, “10 万回転超高速ミーリングにおける超硬小径ボールエンドミルの摩耗特性”, 精密工学会誌, Vol. 65, No. 6 (1999), pp. 867-871.

（9）岩部洋育，山口恒志，清水啓輔，中西賢介，“小径ボールエンドミルによる高硬度材の高速加工における工具寿命 と仕上げ面粗さに関する研究”，日本機械学会論文集 C 編，Vol. 69, No. 687 (2003), pp. 3116-3123.

（10）宮口孝司，获岡悦雄，桝田正美，岩部洋育，“小径ボールエンドミルを用いた高回転ミーリングにおける動的切削 力”，精密工学会誌，Vol. 67, No. 3 (2001), pp. 450-455.

(11) Y.T. Liu, N.H. Chiu, Y.C. Lin, C.L. Lai, Y.F. Lin, H.H. Chiu, "Experimental Study on Milling Hardened SKD Steel Using Micro CBN Ball-End Mills", Advanced Materials Research, Vol. 126-128, (2010), pp. 773-778.

(12) S. Dolinsek, J. Kopac, "Mechanism and types of tool wear; particularities in advanced cutting", Journal of Achievements in Materials and Manufacturing Engineering, Vol. 19, (2006), pp. 11-18. 